\title{
Physical properties of yogurt fortified with various commercial whey protein concentrates
}

\author{
Isabelle Sodini, John Montella and Phillip S Tong
}

Dairy Product Technology Center, California Polytechnic State University, San Luis Obispo, California 93407, USA

\begin{abstract}
The effects of whey protein concentrates on physical and rheological properties of yogurt were studied. Five commercial whey protein concentrates (340 g $\mathrm{kg}^{-1}$ protein nominal) were used to fortify milk to $45 \mathrm{~g}$ protein $\mathrm{kg}^{-1}$. Fermentation was performed with two different starters (ropy and non-ropy). Resulting yogurts were compared with a control yogurt enriched with skim milk powder. The waterholding capacity of the yogurt fortified with skim milk powder was $500 \mathrm{gkg}^{-1}$ and ranged from 600 to $638 \mathrm{~g} \mathrm{~kg}^{-1}$ when fortified with whey protein concentrates. Significant rheological differences have been noticed between the yogurts fortified with different whey protein concentrates, independent of the starter used. Three whey protein concentrates generated yogurts with a behavior similar to the control. The two others produced yogurt with lower firmness (15g compared with $17 \mathrm{~g}$ ), lower Brookfield viscosity (6Pa s compared with 9Pa s), lower yield stress (2Pa compared with 4Pa), lower complex viscosity (13 Pa s compared with $26 \mathrm{~Pa}$ s), and lower apparent viscosity (0.4 Pa s compared with $1 \mathrm{~Pa}$ s) than the control, respectively. The yogurts with the lowest firmness and viscosity were produced with concentrates which contained the highest amount of non-protein nitrogen fraction $\left(160 \mathrm{~g} \mathrm{~kg}^{-1}\right.$
\end{abstract}


versus $126 \mathrm{~g} \mathrm{~kg}^{-1}$ of the total nitrogen), and the highest amount of denaturation of the whey protein (262 versus $200 \mathrm{~g} \mathrm{~kg}^{-1}$ of the total nitrogen).

\section{INTRODUCTION}

Yogurt is a fermented milk product widely consumed around the world. In 2001, more than 9 million tons of yogurt were produced, mostly in Europe (6.6 millions tons). ${ }^{1,2}$ However, it is becoming more popular in other areas. For instance, the yogurt market in the USA has grown over the past few years at an annual growth rate of between $3 \%$ and $10 \% .^{3}$

Manufacture of yogurt usually involves milk fortification with dairy ingredients to increase the concentration of protein to $40-50$ gprotein $\mathrm{kg}^{-1}$. Polysaccharides and stabilizers are sometimes added to improve texture. The fortified milk is homogenized, highly heated $\left(90^{0} \mathrm{C}\right.$ for $\left.10 \mathrm{~min}\right)$, cooled to the fermentation temperature $\left(42^{0} \mathrm{C}\right)$ and inoculated with starter. After inoculation, the process differs depending on the kind of yogurt produced. In the case of set yogurt, the inoculated milk is filled into consumer cups and incubated to the desired $\mathrm{pH}$ (4.5), then cooled to $4^{0} \mathrm{C}$ without disturbing the curd. In the case of stirred yogurt, the inoculated milk is filled into a tank where the fermentation occurs. After fermentation, the gel is broken, then the yogurt is pumped through a fine mesh, cooled and finally packaged into cups. ${ }^{4}$

Traditionally, skim milk powder (SMP) is used to enrich the milk before fermentation. However, increased quality and availability of other dairy ingredients, such as whey protein concentrates (WPCs), may provide a cost-effective alternative to skim milk powder. In addition, whey proteins may offer functional properties different from the whole milk proteins of skim milk powder. Whey protein concentrates are produced by ultrafiltration of whey to enrich the protein fraction by removal of lactose, minerals and other low molecular 
weight components. For manufacture of whey protein concentrates with a high protein content (>600-650 $\mathrm{g} \mathrm{kg}^{-1}$ ), an additional diafiltration step is applied. The protein contents of the WPCs typically range from 340 to $800 \mathrm{~g} \mathrm{~kg}^{-1}$.

The effect of the replacement of SMP by WPC on textural and physical properties of yogurts has been studied by various authors. However, results are inconsistent. Some have reported a positive effect of WPC on yogurt firmness and/or viscosity. ${ }^{6-8}$ In contrast, the studies of Guin'ee et $a l,{ }^{9}$ and GuzmanGonzalez et $a l^{10}$ reported a viscosity similar or weaker when SMP was replaced by WPC. The effect of WPCs on the water-holding capacity of yogurt is also inconsistent. GuzmanGonzalez et $a l^{10}$ and Cheng et $a l^{6}$ showed a better ability to retain water in yogurts containing WPC than in those enriched with SMP. However, Guin'ee et al, ${ }^{9}$ Modler et $a l^{11}$ and Remeuf $e t a l^{7}$ noticed the opposite effect of WPC addition on water retention in yogurt.

These apparent contradictions could be due to many reasons. First, there were different methods used to determine the physical and rheological properties of yogurt in these studies. Some methods focus on the viscoelastic behavior (when the yogurt structure is not affected), while other methods evaluated the flow behavior (when the initial yogurt structure is altered). Differences in starters used to ferment the milk may also influence yogurt properties.12,13 Finally, variations in the functional properties of commercial WPCs ${ }^{14,15}$ may explain some of the inconsistencies between studies. Modler et al $^{11}$ compared three WPCs with 330 to 530 $\mathrm{g} \mathrm{kg}^{-1}$ protein. They reported variation in syneresis (210 to $280 \mathrm{~g} \mathrm{~kg}^{-1}$ of whey expelled during a drainage test) and firmness (49.5 to $78.9 \mathrm{~g}$ ) of the three yogurts. Guin'ee et $a l^{9}$ compared four whey protein concentrates (350 to $750 \mathrm{gkg}^{-1}$ protein). They noticed variation in water-holding capacity (370 to $550 \mathrm{~g} \mathrm{~kg}^{-1}$ of whey expelled during a centrifugation test) and apparent viscosity (0.16 to 1.12 Pa s). GuzmanGonzalez et $a l^{10}$ demonstrated variation in 
water-holding capacity (100 to $300 \mathrm{~g} \mathrm{~kg}^{-1}$ of whey expelled during a centrifugation test) and Brookfield viscosity (10 to $30 \mathrm{~Pa}$ s) with six yogurts produced with six different whey protein concentrates (340 to $800 \mathrm{~g} \mathrm{~kg}^{-1}$ protein).

In recent years, changes in processing whey have improved the consistency and functionality of WPCs. Nevertheless, variation in properties of yogurts fortified with WPCs may still exist. Our objectives were to: (1) characterize the properties of yogurts fortified with commercial WPCs (340 $\mathrm{g} \mathrm{kg}^{-1}$ protein nominal), and (2) determine whether differences in yogurt properties can be related to differences in physicochemical properties of the WPCs.

\section{MATERIALS AND METHODS}

Starters and ingredients

The starter cultures were blends of strains of Streptococcus thermophilus, Lactobacillus delbrueckii subsp bulgaricus, Lactobacillus acidophilus, Bifidobacterium and Lactobacillus paracasei subsp casei. Two different starters were used: Yog-Fast 11 and Yog-Fast 17 (Chr Hansen, Milwaukee, WI, USA). They were characterized as ropy and non-ropy starters, respectively. They were stored at $-70{ }^{\circ} \mathrm{C}$ in a concentrated form prior to use.

Six commercial dairy ingredients were used: a low-heat skim milk powder and five commercial whey protein concentrates $340 \mathrm{~g} \mathrm{~kg}^{-1}$ (WPC1 to WPC5). These concentrates had been provided by different facilities which manufacture WPC from whey resulting from manufacture of cheddar (WPC2, WPC4, WPC5), Mozzarella (WPC1) or various other cheeses (Monterey Jack, Mozzarella, Muenster, and Manchego) (WPC3). 
Yogurt preparation

Milk was standardized to a fat level of $10 \mathrm{~g} \mathrm{~kg}^{-1}$ by blending pasteurized non-fat milk and pasteurized homogenized whole milk (35 $\mathrm{gkg}^{-1} \mathrm{fat}$ ). The protein content was enriched to $45 \mathrm{~g}$ protein $\mathrm{kg}^{-1}$ by the addition of skim milk powder (SMP) or whey protein concentrate (WPC1 to WPC5). One-liter flasks were filled with the standardized and fortified milk, heated without agitation for 55 min in a water bath at $90{ }^{\circ} \mathrm{C}$, then cooled for $1 \mathrm{~h}$ in an ice bath, and stored overnight at $4{ }^{\circ} \mathrm{C}$.

The following day, the milk was preheated to $42^{\circ} \mathrm{C}$, inoculated with $0.2 \mathrm{~g} \mathrm{l}^{-1}$ commercial culture, then incubated at the same temperature until a pH of 4.50 was reached. Fermentation was stopped by rapidly cooling the fermented milk to $25^{\circ} \mathrm{C}$. This was accomplishing by placing the bottles in an ice bath for 15 min while manually stirring the yogurt. The cooled fermented milk was then poured into 100-ml cups at a flow rate of approximately $6 \mathrm{lh}^{-1}$ by means of a 50 -ml syringe (orifice $1 \mathrm{~mm}$ diameter) and was stored overnight at $4{ }^{\circ} \mathrm{C}$. The shear created by pumping the yogurt from a syringe was to simulate the texturization of stirred yogurt which occurs commercially by pumping set yogurt through perforated screens, then filling heads for packaging.

Physicochemical analyses

The $\mathrm{pH}$ values of $100 \mathrm{~g} \mathrm{~kg}^{-1}$ reconstituted whey protein concentrates in deionized water were determined at $20{ }^{\circ} \mathrm{C}$ with a pH meter model 34 (Beckman, Fullerton, CA, USA). Measurements were done in duplicate.

The levels of total nitrogen (TN), nitrogen soluble at pH 4.6 (SN), and non-protein nitrogen (NPN) were determined in the whey protein concentrates, as well as in the mixes, before and after heating, by the Kjeldahl method. ${ }^{16}$ All measurements were carried out in duplicate. 
A multiplication factor of 6.38 was used to convert nitrogen to protein. The non-protein fraction (NP), expressed as protein equivalent, was calculated as NPN $\times 6.38$. The true protein fraction $(\mathrm{TP})$ was calculated as $(\mathrm{TN}-\mathrm{NPN}) \times 6.38$. The fraction of protein soluble at $\mathrm{pH} 4.6(\mathrm{SP})$ was calculated as $(\mathrm{SN}-\mathrm{NPN}) \times 6.38$. The fraction of protein insoluble at pH 4.6 (IP) was calculated as $(\mathrm{TN}-\mathrm{SN}) \times 6.38$.

The fraction of protein soluble at $\mathrm{pH} 4.6$ was determined in the mixes before and after heating (SP1 and SP2, respectively). The extent of protein denaturation (D) occurring in the mixes during the heating was calculated as described by Mottar et al. ${ }^{17}$

$$
D=\frac{\mathrm{SP}_{1}-\mathrm{SP}_{2}}{\mathrm{SP}_{1}} \times 100 \%
$$

Moisture, fat content and ash were determined in whey protein concentrate. Moisture was determined Yogurt fortification with whey protein concentrates by drying for $5 \mathrm{~h}$ in a vacuum oven at $100{ }^{\circ} \mathrm{C} .{ }^{18}$ Fat content was determined by the Babcock method. ${ }^{19}$ Ash content was determined by ignition at $550{ }^{\circ} \mathrm{C}$ in an electric muffle furnace. ${ }^{20}$ All the measurements were carried out in triplicate. Lactose content was calculated by difference \{total solid - (total protein + fat + ash) $\}$ as described by GuzmanGonzalez et al. ${ }^{10}$

Physical evaluations

Three different analyses were carried out on the yogurts after $16 \mathrm{~h}$ of storage at $4^{\circ} \mathrm{C}$ to determine their physical properties. Before each analysis, the yogurt was gently stirred by making five up and down movements of a spoon in the yogurt cup to ensure homogeneity, as reported by Remeuf et al. ${ }^{7}$

The water-holding capacity was determined by a procedure adapted from GuzmanGonzalez et al. ${ }^{10}$ A sample of about $20 \mathrm{~g}$ of yogurt $(Y)$ was centrifuged for $10 \mathrm{~min}$ at 
$1250 \mathrm{x} g$ at $4{ }^{\circ} \mathrm{C}$. The whey expelled $(W)$ was removed and weighed. The water-holding capacity $\left(\mathrm{WHC}, \mathrm{gkg}^{-1}\right)$ was calculated as: WHC $=(Y-W) / Y \times 1000$

The measurement was carried out in triplicate.

A puncture test was carried out with a TAXT2 texture analyzer (Stable Micro Systems Ltd, Haslemere, UK) using a 2.5-cm acrylic cylinder probe. The test speed was fixed at 2 $\mathrm{mm} \mathrm{s}^{-1}$ and the penetration depth was $10 \mathrm{~mm}$. The sample temperature was $4^{\circ} \mathrm{C}$. The test was replicated three times. Firmness was defined as the force necessary to reach the maximum depth.

Viscosity was measured using a Brookfield DVII viscosimeter (Brookfield, Middleboro, MA, USA) with a Helipath (T Spindle, type D) rotated at $2.5 \mathrm{rev} \mathrm{min}^{-1}$ during 1 min. Sample temperature was

$4{ }^{\circ} \mathrm{C}$. The test was replicated three times. The viscosity determined with the Brookfield viscometer is known as the Brookfield viscosity in the following text of this paper to distinguish it from the apparent viscosity measured by the rheometer. Rheological evaluations Three tests were conducted at $10{ }^{\circ} \mathrm{C}$ with a controlled stress rheometer (model SR5000; Rheometric Scientific Inc, Piscataway, NJ, USA), used in harmonic and stationary modes. The rheometer was equipped with a concentric cylinder device consisting of a cup (32 mm diameter) and a bob (29.5 mm diameter, $44.25 \mathrm{~mm}$ length). About $17 \mathrm{ml}$ of yogurt sample was transferred into the cup of the rheometer and the bob was lowered until its whole surface was covered. Five minutes were allotted for the sample temperature to equilibrate to $10{ }^{\circ} \mathrm{C}$ prior each analysis.

Measurements in harmonic mode were used to characterize the viscoelastic behavior (where original sample structure is not affected), and carried out using a stress sweep (1-100 Pa, 
frequency $1 \mathrm{~Hz}, 20$ cycles per decade of stress) to determine the range of linear viscoelasticity. The complex viscosity, in Pa s, was calculated at $1 \mathrm{~Pa}$, which was in the range of linear viscoelasticity.

Measurements in stationary mode (where the original sample structure is disrupted) were used to characterize the flow behavior. The determination of yield stress was carried out following the procedure of Benezech et al. ${ }^{21}$ The sample of yogurt was subjected to a small shear stress $(1 \mathrm{~Pa})$ and the shear stress was increased in increments of $0.5 \mathrm{~Pa}$ until the recorded strain increased continuously. The duration of each step was $30 \mathrm{~s}$. The yield stress in Pa was defined as the stress required to increase the strain continuously. Apparent viscosity in Pa s was determined after 3 min of shearing by applying a stress of $20 \mathrm{~Pa}$.

For all tests, three replicates were performed and a fresh sample was used for each replicate. Statistical analyses

Results were evaluated statistically using Minitab ${ }^{\mathrm{TM}}$ 13.1 Software (Minitab Inc, State College, PA, USA). A one-factor analysis of variance was performed to determine the effect of the dairy ingredient on the protein composition of the mixes (true protein content and degree of denaturation for the whey protein). A two-factor analysis of variance with interaction was performed to determine the effects of both starter and dairy ingredient on the physical and rheological properties of the resulting yogurts. For each main effect, a multiple comparison of treatment means was performed using Tukey's pair-wise comparison at a $a$ level of 5\%. The relationships between physical and rheological properties of the yogurt were investigated by evaluating the correlation matrix. 


\section{RESULTS AND DISCUSSION}

Physicochemical characteristics of the dairy powders

\section{Proximate composition of the dairy powders}

The proximate compositions on a dry matter basis of the five commercial WPC are given in table 1. The $\mathrm{pH}$ was between 6.30 and 6.5, except for WPC5, for which $\mathrm{pH}$ was 6.84. Probably a neutralization with $\mathrm{NaOH}$ was done for this product before the drying, as previously reported.10,15 Fat content was in the range 21-37 g kg-1 and ash content was approximately $70 \mathrm{~g} \mathrm{~kg}-1$. These values are comparable with those obtained by Guzman Gonzalez et al.10 For total protein, the content was higher than $340 \mathrm{~g} \mathrm{~kg}-1$. One whey protein concentrate (WPC2) had a significantly higher total protein content (376.5 $\mathrm{g} \mathrm{kg}-1$ ) than the others (350-360 g kg-1). [Table 1]

Nitrogen fractions of the dairy powders

The contents of the nitrogen fractions of the whey protein concentrates (non-protein nitrogen, soluble and insoluble protein at $\mathrm{pH}$ 4.6) are detailed in Table 2. The whey protein concentrate WPC5 had a high non-protein nitrogen content (160 g kg-1 of the nitrogen fraction) compared with approximately $126 \mathrm{~g} \mathrm{kg-1} \mathrm{for} \mathrm{the} \mathrm{other} \mathrm{whey} \mathrm{protein} \mathrm{concentrates;} \mathrm{the} \mathrm{difference} \mathrm{was}$ significant $(p \leq 0.05)$. This could be due to a higher level of microbial proteolysis during cheesemaking and the storage of whey before concentration and drying, or to a higher retention of the NPN fraction during ultrafiltration. The fraction of insoluble protein at $\mathrm{pH} 4.6$ estimates the denaturation of the whey protein occurring during manufacture.15 The fractions of insoluble protein at $\mathrm{pH} 4.6$ determined in our study (190 to $260 \mathrm{~g} \mathrm{~kg}-1$ of the nitrogen fraction) were higher than those obtained by GuzmanGonzalez et al10 (50 to $210 \mathrm{~g} \mathrm{~kg}-1$ of the nitrogen fraction). There were significant differences $(p \leq 0.05)$ between the five whey protein 
concentrates. The fraction of insoluble protein at $\mathrm{pH} 4.6$ was $262 \mathrm{~g} \mathrm{~kg}-1$ of the nitrogen fraction for WPC4, compared with $200 \mathrm{~g} \mathrm{~kg}-1$ of the nitrogen fraction for the other WPC. Therefore, the heat treatment was probably more severe for this product. [Table 2] [Table 3] [Figure 1] [Figure 2]

Physicochemical characteristics of the mixes

The true protein content and the degree of denaturation of the whey protein in the mixes, which are key factors for the physical and rheological properties of the yogurts,22 were determined for each replicate. The average values are reported in Table 3. The content of true protein was not significantly different between the six mixes (approximately $41 \mathrm{~g}$ protein $\mathrm{kg}-1$ ). The denaturation of the whey protein fraction during the heating was high (72.9-77.5\%), due to the high heat treatment applied to the fortified milk. This high heat treatment is commonly used in yogurt manufacture to obtain the desired texture. By applying different heat treatments to mixes, it was demonstrated that the highest viscosity was obtained with the highest heat treatment, because it led to the highest level of whey protein denaturation.23 The denatured whey protein resulting from the heating of the milk interacts with $\kappa$-casein, coats the micelles, and enhances the cross-linking of the gel.17 The degree of denaturation was not significantly different between the five mixes enriched with WPC (ca 76.6\%).

Physical and rheological properties of the yogurts Effect of starter on physical and rheological properties of the yogurts

The effect of starter on the properties of the yogurt was significant $(p \leq 0.01)$ for two rheological parameters: the yield stress and the complex viscosity. These results are presented in Figs 1 and 2, respectively. Independent of the ingredient used to fortify the milk, the yogurt obtained with the ropy starter gave lower values for complex viscosity and yield stress compared with those 
obtained with the non-ropy starter. On average, yield stress and complex viscosity were equal to 2.85 Pa and 18.5 Pa s, respectively, for yogurt fermented with ropy starter, compared with 3.83 Pa and 22.8 Pa s for yogurt fermented with nonropy starter. These results are consistent with those previously reported by Rohm et al,13 Hess et al12 and Hassan et al.24 The lower value observed in yogurt produced with the ropy starter can be attributed to the production of exopolysaccharide by the starter. The filaments of exopolysaccharides interfere with the casein network. It can be assumed that protein strand formation and protein-protein interaction is partly inhibited by the exopolysaccharides, thus reducing the rigidity of the resulting yogurt gel. Effect of dairy powders on physical and rheological properties of the yogurts The effect of the dairy ingredient source used for fortification was significant ( $p \leq$ 0.01) for all the physical and rheological parameters of yogurt evaluated. The results are summarized in Table 3. The water-holding capacity of yogurts enriched with whey protein concentrates was higher than that of control yogurt. The water-holding capacity of WPC enriched yogurts was 601 to $636 \mathrm{gkg}^{-1}$, compared with $501 \mathrm{~g} \mathrm{~kg}^{-1}$ for control yogurt, which represented a 25\% difference. These results are comparable with previous works, ${ }^{6,10}$ and may be due to a higher cross-linkage of the network noticed in yogurts fortified with whey protein concentrates. ${ }^{7,8}$

For the other descriptors (firmness, Brookfield viscosity, rheological parameters), the highest values were obtained with the yogurts enriched with skim milk powder (control) or with whey protein concentrates WPC1, WPC2, and WPC3, while the lowest values were recorded with the yogurts fortified with whey protein concentrates WPC4 and WPC5. The data demonstrated a strong variation in functionality of the commercial 
preparations of $340 \mathrm{~g} \mathrm{~kg}^{-1}$ WPC for yogurt application, and agreed with the results of previous studies using WPC.9-11

Relationships between the physical and rheological properties of the yogurts and the physicochemical characteristics of the dairy powders

Some differences in physicochemical characteristics of the dairy powders were found in WPC4 and WPC5, and these resulted in yogurts with the lowest firmness, Brookfield viscosity, yield stress, and complex and apparent viscosity, compared with the other WPCs. There was a higher content of NPN in WPC5, and a higher level of denatured whey protein in WPC4, than in the other whey protein concentrates. A high level of NPN suggests a high level of proteolysis, and could influence the functionality of the whey protein concentrate. A high level of denaturation of whey protein has been shown to decrease the firmness of a heatinduced whey protein gel. ${ }^{15}$ For lactic gels, no studies have been carried out to relate the degree of denaturation of the whey protein concentrates to their functionality. However, the acid gelation behavior of co-heated casein micelle/whey mixtures has been recently compared with systems where whey proteins were heated separately before mixing with the casein micelles. ${ }^{25}$ The results demonstrated that the presence of denatured whey protein before mixing with casein led to a less homogeneous gel with a more open structure than in a system where whey proteins are denatured in the presence of casein. These authors suggest that a pre-denaturation of the whey protein is detrimental to the structure of the gel because it generates some large aggregates of denatured whey proteins, which would not coat the casein micelles. This could partially explain the lower texturing ability of WPC4 compared to the other WPC's. 
Other physicochemical characteristics are probably involved in the definition of the texturing ability of the whey protein concentrates. The balance between the minerals, which has not been

determined in this study, has been shown to affect the physical properties of the yogurt. ${ }^{10}$ [Table 4] [Figure 3]

\section{REFERENCES}

1 International Dairy Foods Association, Milk facts, International Dairy Foods Association, Washington (2002).

2 IDF, World Dairy Situation, Bulletin of the International Dairy Federation n 378, IDF, Brussels (2002).

3 Sanders ME, Market and regulatory challenges for functional dairy foods: communicating health benefits. Bull Int Dairy Fed 375:17-19 (2002).

4 Tamime AY and Robinson RK, Yoghurt: science and technology, 2nd edn. Woodhead Publishing Limited, Cambridge (1999).

5 ZadowJG, Whey and lactose processing. Elsevier Applied Science, Barking, UK (1992).

6 Cheng LJ, Augustin MA and Clarke PT, Yogurts from skim milk—whey protein concentrate blends. Australian Journal of Dairy Technology 55:110 (2000).

7 Remeuf F, Mohammed S, Sodini I and Tissier JP, Preliminary observations on the effects of milk fortification and heating on microstructure and physical properties of stirred yogurt. Int Dairy J 13:773-782 (2003).

8 Puvanenthiran A, Williams RPW and Augustin MA, Structure and visco-elastic properties of set yoghurt with altered casein to whey protein ratios. Int Dairy J 12:383-391 (2002). 
9 Guinee TP, Mullins CG, Reville WJ and Cotter MP, Physical properties of stirred-curd unsweetened yoghurts stabilized with different dairy ingredients. Milchwissenschaft 50:196200 (1995).

10 GuzmanGonzalez M, Morais F, Ramos M and Amigo L, Influence of skimmed milk concentrate replacement by dry dairy products in a low fat set-type yoghurt model system. I: Use of whey protein concentrates, milk protein concentrates and skimmed milk powder. $J$ Sci Food Agric 79:1117-1122 (1999).

11 Modler HW, LarmondME, Lin CS, Froelich D and Emmons DB, Physical and sensory properties of yogurt stabilized with milk proteins. J Dairy Sci 66:422-429 (1983).

12 Hess SJ, Roberts RF and Ziegler GR, Rheological properties of nonfat yogurt stabilized using Lactobacillus delbrueckii ssp bulgaricus producing exopolysaccharide or using commercial stabilizer systems. Y Dairy Sci 80:252-263 (1997).

13 Rohm H and Kovac A, Effect of starter cultures on linear viscoelastic and physical properties of yoghurt gels. Y Texture Studies 25:311-329 (1994).

14 Holt C, McPhail D, Nylander T, Otte J, Ipsen RH, Bauer R, Ogendal L, Olieman K, de Kruif CG, Leonil J, Molle D, Henry G, Maubois JL, Dolores Perez M, Puyol P, Calvo M, Bury SM, Kontopidis G, McNae I, Sawyer L, Ragona L, Zetta L, Molinari H, Klarenbeek B, Jonkman MJ, Moulin J and Chatterton D, Some physico-chemical properties of nine commercial or semi-commercial whey protein concentrates, isolates and fractions. Int $Y$ Food Sci Technol 34:587-601 (1999).

15 De Wit JN, Klarenbeek G and Adamse M, Evaluation and functional properties of whey protein concentrates and whey protein isolates. 2. Effects of processing history and composition. Netherland Milk Dairy Y 40:41-56 (1986). 
16 Rowland SJ, The determination of nitrogen distribution of milk. Y Dairy Res 9:42-46 (1938).

17 Mottar J, Bassier A, Joniau M and Baert J, Effect ofheat induced association of whey proteins and casein micelles on yogurt texture. Y Dairy Sci 72:2247-2256 (1989).

18 American Dairy Products Institute, Standards for grades of dry milks, bulletin 916, Determination of moisture, vacuum oven method, American Dairy Products Institute, Chicago (1990).

19 Association of Official Analytical Chemists, Official Methods of Analysis, 16th edn, Method 989.04. Association of Official Analytical Chemists, Gaithersburg (1995).

20 Association of Official Analytical Chemists, Official Methods of Analysis, 16th edn, Method 930.30. Association of Official Analytical Chemists, Gaithersburg (1995).

21 Benezech T and Maingonnat JF, Flow properties of stirred yoghurt: structural parameter approach in describing time-dependency. Y Texture Studies 24:455-473 (1993).

22 Sodini I, Remeuf F, Haddad S and Corrieu G, The relative effect of milk base, starter, and process on yogurt texture: a review. Crit Rev Food Sci Nutr 44:113-137 (2004).

23 Parnell-Clunies E, Kakuda Y and deMan JM, Influence of heat treatment of milk on the flow properties of yoghurt. Y Food Sci 51:1459-1462 (1986).

24 Hassan AN, Corredig M and Frank JF, Viscoelastic properties of yogurt made with ropy and non-ropy exopolysaccharides producing cultures. Milchwiss-Milk Sci Int 56:684-687 (2001).

25 Schorsch C, Wilkins DK, Jones MG and Norton IT, Gelation of casein-whey mixtures: effects of heating whey proteins alone or in the presence of casein micelles. Y Dairy Res 68:471-481 (2001). 
26 Ramaswamy HS and Basak S, Rheology of stirred yogurts. Y Texture Studies 22:231-241 (1991). 


\begin{tabular}{lccccc}
\hline Ingredient & $\mathrm{pH}^{\mathrm{b}}$ & Fat & Ash & Crude protein & Lactose $^{\mathrm{c}}$ \\
\hline WPC1 & $6.31^{\mathrm{c}}$ & $35.6^{\mathrm{ab}}$ & $64.0^{\mathrm{e}}$ & $354.1^{\mathrm{b}}$ & 546.3 \\
WPC2 & $6.47^{\mathrm{b}}$ & $24.9^{\mathrm{cd}}$ & $69.4^{\mathrm{b}}$ & $376.5^{\mathrm{a}}$ & 529.2 \\
WPC3 & $6.49^{\mathrm{b}}$ & $29.7^{\mathrm{bc}}$ & $76.3^{\mathrm{a}}$ & $348.8^{\mathrm{b}}$ & 545.2 \\
WPC4 & $6.30^{\mathrm{c}}$ & $36.8^{\mathrm{a}}$ & $65.9^{\mathrm{d}}$ & $359.9^{\mathrm{b}}$ & 537.4 \\
WPC5 & $6.84^{\mathrm{a}}$ & $21.0^{\mathrm{d}}$ & $67.1^{\mathrm{c}}$ & $353.9^{\mathrm{b}}$ & 558.0 \\
\hline
\end{tabular}

a Means within a column not sharing a common superscript differ significantly $(p \leq 0.05)$.

${ }^{b}$ Measured in a $100 \mathrm{~g} \mathrm{~kg}^{-1}$ reconstitution.

${ }^{\circ}$ Calculated by difference.

Table 1. Compositions (gkg-1) on a dry matter basis of the five commercial whey protein concentrates (WPC1 to WPC5). averages of two determinationsa.

\begin{tabular}{lccc}
\hline Ingredient & $\begin{array}{c}\text { Non-protein } \\
\text { nitrogen }\end{array}$ & $\begin{array}{c}\text { Insoluble protein } \\
\text { at } \mathrm{pH} 4.6\end{array}$ & $\begin{array}{c}\text { Soluble protein } \\
\text { at } \mathrm{pH} 4.6\end{array}$ \\
\hline WPC1 & $123^{\mathrm{b}}$ & $209^{\mathrm{b}}$ & $668^{\mathrm{ab}}$ \\
WPC2 & $107^{\mathrm{b}}$ & $193^{\mathrm{b}}$ & $700^{\mathrm{a}}$ \\
WPC3 & $114^{\mathrm{b}}$ & $207^{\mathrm{b}}$ & $679^{\mathrm{ab}}$ \\
WPC4 & $118^{\mathrm{b}}$ & $262^{\mathrm{a}}$ & $620^{\mathrm{b}}$ \\
WPC5 & $160^{\mathrm{a}}$ & $189^{\mathrm{b}}$ & $651^{\mathrm{ab}}$ \\
\hline
\end{tabular}

a Means within a column not sharing a common superscript differ significantly $(p \leq 0.05)$.

Table 2. Contents (gkg-1) of the nitrogen fractions of the five commercial whey protein concentrates (WPC1 to WPC5), (averages of two determinations)a. 


\begin{tabular}{|c|c|c|c|c|c|c|}
\hline & SMP & WPC1 & WPC2 & WPC3 & WPC4 & WPC5 \\
\hline \multicolumn{7}{|l|}{ Protein composition of the mixes } \\
\hline True protein $\left(\mathrm{g} \mathrm{kg}^{-1}\right)$ & $41.8^{\mathrm{a}}$ & $40.5^{\mathrm{a}}$ & $40.9^{a}$ & $40.3^{\mathrm{a}}$ & $40.6^{a}$ & $40.0^{\mathrm{a}}$ \\
\hline Whey protein denaturation (\%) & $72.9^{\mathrm{b}}$ & $77.5^{\mathrm{a}}$ & $77.2^{\mathrm{a}}$ & $76.1^{\mathrm{ab}}$ & $76.7^{\mathrm{a}}$ & $75.5^{\mathrm{ab}}$ \\
\hline \multicolumn{7}{|c|}{ Physical and meological properties of the yogurts } \\
\hline Water-holding capacity $\left(\mathrm{g} \mathrm{kg}^{-1}\right)$ & $501^{\mathrm{c}}$ & $636^{a}$ & $638^{a}$ & $631^{a}$ & $625^{a b}$ & $601^{b}$ \\
\hline Firmness (g) & $17.7^{\mathrm{a}}$ & $17.3^{\mathrm{a}}$ & $16.2^{\mathrm{b}}$ & $16.3^{\mathrm{b}}$ & $15.1^{c}$ & $15.2^{\mathrm{c}}$ \\
\hline Brookfield viscosity (Pa s) & $9.33^{\mathrm{a}}$ & $10.28^{a}$ & $9.46^{\mathrm{a}}$ & $8.54^{\mathrm{ab}}$ & $7.40^{\mathrm{bc}}$ & $6.32^{\mathrm{C}}$ \\
\hline Yield stress $(\mathrm{Pa})$ & $3.62^{\mathrm{a}}$ & $3.93^{\mathrm{a}}$ & $4.25^{a}$ & $3.57^{\mathrm{a}}$ & $2.55^{\mathrm{b}}$ & $2.27^{b}$ \\
\hline Complex viscosity (Pa s) & $25.8^{\mathrm{a}}$ & $24.3^{a}$ & $22.9^{\mathrm{ab}}$ & $20.4^{\mathrm{b}}$ & $16.0^{\circ}$ & $13.4^{\mathrm{c}}$ \\
\hline Apparent viscosity (Pa s) & $1.10^{\mathrm{a}}$ & $0.78^{b}$ & $0.84^{b}$ & $0.58^{c}$ & $0.40^{\mathrm{cd}}$ & $0.38^{d}$ \\
\hline
\end{tabular}

One mix was enriched with skim milk powder (SMP). The five others were enriched with various commercial whey protein concentrates (WPC1 to WPC5). The presented values are the means obtained with two different starters (ropy and non ropy). Each assay has been performed in duplicate. Means within a row not sharing a common superscript differ significantly $(p \leq 0.05)$.

Table 3. Physicochemical characteristics (true protein content and whey protein denaturation), of

the mixes, and physical and rheological properties (water-holding capacity, firmness, Brookfield viscosity, yield stress, apparent viscosity, and complex viscosity) of the resulting yogurts.

\begin{tabular}{lccccc}
\hline & $\begin{array}{c}\text { Water-holding } \\
\text { capacity }\left(\mathrm{g} \mathrm{kg}^{-1}\right)\end{array}$ & $\begin{array}{c}\text { Firmness } \\
(\mathrm{g})\end{array}$ & $\begin{array}{c}\text { Brookfield viscosity } \\
(\mathrm{Pa} \mathrm{s})\end{array}$ & $\begin{array}{c}\text { Yield stress } \\
(\mathrm{Pa})\end{array}$ & $\begin{array}{c}\text { Complex viscosity } \\
(\mathrm{Pa} \mathrm{s})\end{array}$ \\
\hline Firmness (g) & -0.466 & - & & & \\
Brookfield viscosity (Pa s) & 0.025 & $0.709^{\mathrm{c}}$ & & & \\
Yield stress (Pa) & -0.085 & $0.622^{\mathrm{c}}$ & $0.739^{\mathrm{b}}$ & $0.887^{\mathrm{a}}$ & $0.656^{\mathrm{c}}$ \\
Complex viscosity (Pa s) & -0.316 & $0.865^{\mathrm{a}}$ & $0.796^{\mathrm{b}}$ & 0.462 & $0.703^{\mathrm{c}}$ \\
Apparent viscosity (Pa s) & -0.445 & $0.609^{\mathrm{c}}$ & & &
\end{tabular}

a,b,c Significant coefficient, $p \leq 0.001, p \leq 0.01, p \leq 0.05$, respectively.

Table 4. Correlation between physical properties of yogurts. 


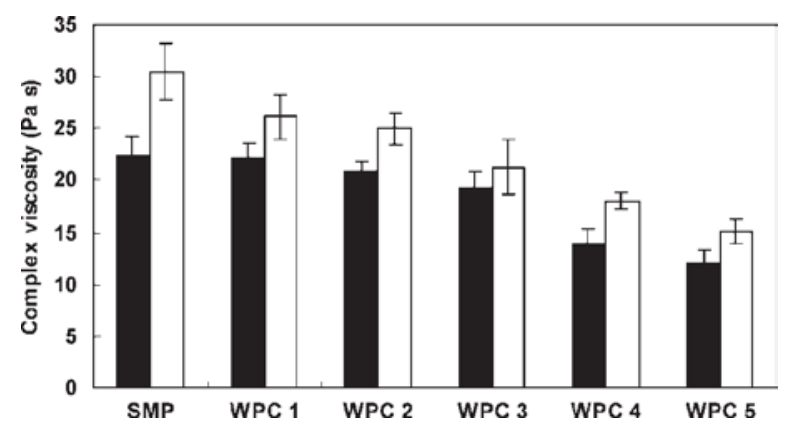

Figure 1. Effect of milk fortification and starter on complex viscosity of yogurt. Milk was enriched with skim milk powder (SMP) or with various commercial whey protein concentrates (WPC1 to WPC5). The milk was fermented by a ropy starter (_) or a non-ropy starter (_). The presented data correspond to two replications of each combination of milk fortification and starter

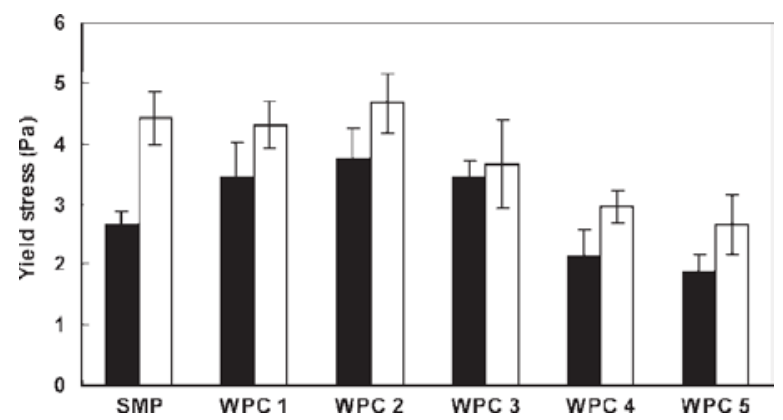

Figure 2. Effect of milk fortification and starter on yield stress of yogurt. Milk was enriched with skim milk powder (SMP) or with various commercial whey protein concentrates (WPC1 to WPC5). The milk was fermented by a ropy starter (_) or a non-ropy-starter (_). The presented data correspond to two replications of each combination of milk fortification and starter. 


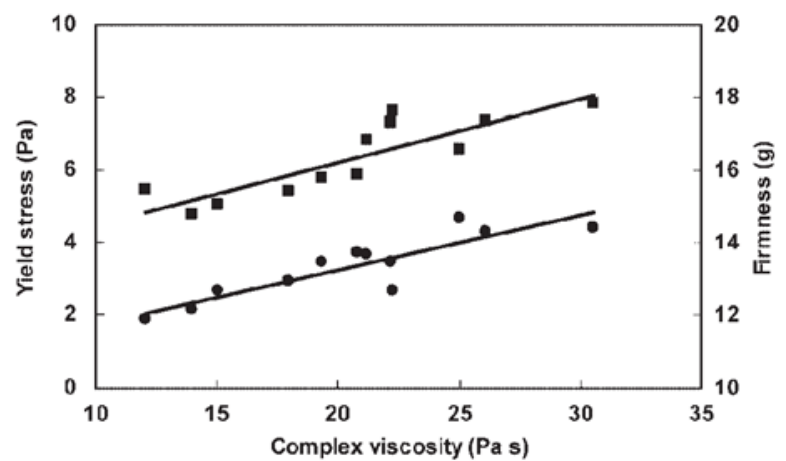

Figure 3. Relationship between complex viscosity (Pa s) and yield stress (Pa) (̌̌) and between complex viscosity (Pa s) and firmness (g) (_) for 12 yogurts obtained with different combinations of milk fortification and starter. The presented data correspond to two replications of each combination. 